\title{
EFFECT OF SAPONIN AS DEFAUNATING AGENT ON IN VITRO RUMINAL FERMENTATION OF FORAGE AND CONCENTRATE
}

\author{
C. Hanim, L. M. Yusiati and S. Alim \\ Laboratory of Nutritional Biochemistry, Faculty of Animal Science, \\ Gadjah Mada University, Jl. Fauna 3 Yogyakarta 55281 - Indonesia \\ CorrespondingE-mail: c.hanim@ugm.ac.id
}

Received November 02, 2009; Accepted November 30, 2009

\begin{abstract}
This research was arranged with a $4 \times 3$ factorial design of treatments to investigate the effect of saponin level in fermentation medium $(0,0.1,0.2$, or $0.3 \mathrm{mg} / \mathrm{ml})$, and many kinds of feed (king grass, rice bran, and king grass:rice bran, 60:40 w/w) on protozoa numbers, ammonia concentration, microbial protein, $\mathrm{pH}$ and cellullase activity. Each treatment was consisted of three replicates. Fermentation was done in syringe and used in vitro gas production medium. The data obtained were analyzed by variance analysis using factorial design (4x3). The differences between mean values were analyzed by Duncan's new multiple range test (DMRT). The result showed that protozoa numbers decreased 17.22, 42.73 and $49.57 \%(\mathrm{P}<0.01)$ for $0.1,0.2$, and $0.3 \mathrm{mg} / \mathrm{ml}$ saponin, respectively from $8.19 \times 10^{3} / \mathrm{ml}$ in the control. The addition of $0.1 \mathrm{mg} / 1 \mathrm{saponin}$ increased ammonia concentration from $33.04 \mathrm{mg} / 100 \mathrm{ml}$ (without saponin) to $37.12 \mathrm{mg} / 100 \mathrm{ml}(\mathrm{P}<0,01)$, whereas the addition of 0.2 and $0.3 \mathrm{mg} / \mathrm{ml}$ saponin decreased ammonia concentrations by 1.69 and $16.50 \%(\mathrm{P}<0.01)$ compared to the control. Microbial protein, cellullase activity and $\mathrm{pH}$ were not affected neither by saponin nor kind of feed. Protozoal numbers and ammonia concentration in the rumen were lower $(\mathrm{P}<0.01)$ with king grass as substrat than that with rice bran, or king grass: rice bran. In general, no interactions between saponin and kind of feed were observed, except for ammonia concentration. It can be concluded that level of $0.2 \mathrm{mg} / \mathrm{ml}$ saponin have antimicrobial properties, particularly in suppressing protozoa, which may prove beneficial to ruminal fermentation and may lead to lower ruminal ammonia concentration, but it did not have negative effect on $\mathrm{pH}$, microbial protein and cellullase activity. King grass as a substrate decreases protozoa numbers and ammonia concentration.
\end{abstract}

Keywords: defaunation, in vitro rumen fermentation, protozoa, saponin

\section{INTRODUCTION}

Saponins are glycosidic compounds composed of a steroid (C27) or triterpenoid (C30) sapogenin nucleus with one or more carbohydrate branches (Klita et al., 1996). Sarsaponin is a group of steroidal glycosides extracted from the Yucca schidigera plant. Steroidal saponins are present in a wide variety of plants, including the desert plant, Yucca schidigera. Saponins have antimicrobial properties, particularly in suppressing ciliate protozoa, peptidase-producing bacteria (Wallace et al., 1994; Wang et al., 2000), and cellulolytic bacteria (Wang et al., 2000). Methanogenic bacteria were metabolically correlated with ciliate protozoa (Newbold et al., 1995 cit. Pen et al., 2006). Because methane production has a negative correlation with energy utilization in ruminants (Ørskov et al., 1968), there have been many efforts to inhibit its production and to rechannel hydrogen to produce more VFA and microbial mass.

In tropical ruminant feeding systems, forages usually have a low digestibility and are deficient in $\mathrm{N}$, which restricts the efficiency of feed utilization. Abreu et al. (2004) explained that feed utilization could be improved by manipulation of ruminal fermentation either through changes in diet composition (e.g., legume supplementation) or through manipulation of key ruminal microbial groups. Removing ruminal ciliate protozoa has been proposed as one of promising approach because their presence decreases bacterial count and the total amount of microbial protein leaving the rumen. A range of techniques for defaunation has been tested, but suitable methods for defaunation under normal farm conditions are still lacking.

Recently, plant secondary metabolites with an inherent capability to partially defaunate the 
rumen have been described. The incorporation of pure saponins or saponin-rich feeds, such as Sapindus saponaria fruits, into the diet decreased the ruminal ciliate population, whereas bacterial and fungal biomass increased (Diaz et al., 1993). Supplementing grass-alone and grass-legume diets with S.saponaria fruits resulted in favorable ruminal changes in vitro, but effects occasionally depended on the basal diet (Hess et al., 2003). Many compounds have been tested in vitro as methane inhibitors. However, ruminal microbial populations in vivo adapt or in vitro degrade many of these compounds, and favorable effects on animal performance have rarely been observed.

The objective of the present study was to investigate the effects of addition of saponin as defaunating agent in ruminal fermentation characteristics of forage and concentrate on protozoal numbers, $\mathrm{pH}$, ammonia concentration, microbial protein and cellullase activity.

\section{MATERIALS AND METHODS}

\section{Experimental Design}

Treatments were arranged in a $4 \times 3$ factorial, with the main factors being level of saponin (containing $0,0.1,0.2$, or $0.3 \mathrm{mg} / \mathrm{ml}$ saponins in fermentation medium) and kind of feed (king grass [Pennisetum hybrid], rice bran, and king grass-rice bran [60:40, w/w]). In vitro fermentation experiments were separately conducted for each treatment with three replicates.

\section{In Vitro Batch Fermentation}

Short-term in vitro incubation were carried out with rumen fluid from a fistulated Ongole Crossbred. The rumen fluid was withdrawn before the morning feeding and was squeezed through four layers of surgical gauze into an Erlenmeyer flask under continuous flushing with $\mathrm{CO}_{2}$, and efforts were made to maintain the temperature at 38 to $39^{\circ} \mathrm{C}$. The fluid was then mixed by a bicarbonic buffer for in vitro gas production $\mathrm{pH}$ 6.9 in a ratio of $1: 2(\mathrm{v} / \mathrm{v})$ as described by Menke and Steingass (1988). The substrate (feed) was milled to pass through $1 \mathrm{~mm}$ sieve and $300 \mathrm{mg}$ was weighed in $100-\mathrm{ml}$ glass syringes. After mixing, $30 \mathrm{ml}$ of diluted rumen fluid was anaerobically transferred to glass syringe containing $300 \mathrm{mg}$ of each substrate. Weighed amounts of saponin were added to achieve final concentrations of $0,0.1,0.2$, or $0.3 \mathrm{mg} / \mathrm{ml}$ of fermentation medium. Each glass syringe was sealed by syringe cap and was incubated in a water bath at $39^{\circ} \mathrm{C}$ for $72 \mathrm{~h}$.

At the end of the incubation period, protozoal numbers and $\mathrm{pH}$ was determined in fermentation fluid. Bacteria were isolated from fermentation fluid using differential centrifugation. In the first step, fermentation fluid was centrifuged at $3000 \mathrm{rpm}$ for $15 \mathrm{~min}$ to separate bacteria from protozoa and feed particles. The resulting supernatant was analyzed for ammonia concentration. A part of supernatants were again centrifuged at $10.000 \mathrm{rpm}$ for $15 \mathrm{~min}$ $\left(5^{\circ} \mathrm{C}\right)$, the cell-free supernatant was analyzed for cellullase activity (CMC-ase) and the pellets were analyzed for microbial protein.

\section{Measurement of In Vitro Fermentation Parameters}

Protozoal Counts. Ruminal protozoa were counted by a $0.2-\mathrm{mm}$ depth counting chamber (Diaz et al., 1993). Before being counted, samples were fixed by the addition of $0.8 \mathrm{ml} / \mathrm{ml}$ of formaldehyde-saline solution $(37 \% \quad[\mathrm{v} / \mathrm{v}]$ formaldehyde and $0.9 \%[\mathrm{w} / \mathrm{v}] \mathrm{NaCl})$. Then, the samples were shaken to ensure homogenity and were transferred via a pipet to the edge of the cover slip, allowing the $0.2-\mathrm{mm}$ deep chamber to fill by capillary action and thereby ensuring that there was no bubble formation under the cover glass. The primary square of the counting chamber was visualized under a microscope at 40 $\mathrm{x}$ magnification.

Fermentation fluid pH. Rumen fluid $\mathrm{pH}$ was immediately recorded using a $\mathrm{pH}$ meter.

Ammonia concentration. After centrifuging at $3.000 \mathrm{rpm}$ for $15 \mathrm{~min}$, supernatant was assayed for ammonia, which was analyzed by the phenolhypochlorite method (Weatherburn, 1967). This method was based on iodophenol reaction resulting stable blue colour, and was measured at $630 \mathrm{~nm}$.

Microbial protein. The pellets were resuspended using a $1 \mathrm{~N} \mathrm{NaCl}$ solution and were analyzed for microbial protein by the Lowry method with bovine serum albumin (BSA) as the standard (Plummer, 1978). Five milliliter of 'alkaline solution' were added to $1 \mathrm{ml}$ of the test solution, and were allowed to stand at room temperature for $10 \mathrm{~min}$. Then it was added by 0.5 $\mathrm{ml}$ of diluted Folin-Ciocalteau reagent. After 30 min the result was read the extinction against the appropriate blank at $750 \mathrm{~nm}$. The values obtained were converted to milligrams of bacterial mass protein per milliliter of broth. 
Cellullase activity. To determine ruminal cellullase activity, the cell-free supernatant was analyzed for cellullase as described by Halliwell et al. (1985). Cellullase activity was determined by measuring reducing sugar released using ferricyanide reaction. One milliliter of supernatant was incubated by $1 \mathrm{ml}$ of $1 \%$ CM-cellulose in 0.1 $\mathrm{M}$ sodium acetate buffer $(\mathrm{pH} 5.5)$ at $38^{\circ} \mathrm{C}$ for 45 min. The reducing sugar thus released was estimated by ferricyanide reaction. The optical density was calibrated by glucose solutions of known concentration. Appropriate blanks were used. Enzyme activity was expressed as unit per $g$ of enzyme protein $(\mathrm{U} / \mathrm{g})$. One unit of each enzyme activity was defined as the amount of enzyme which released $1 \mu \mathrm{mol}$ of reducing sugar per $\mathrm{ml}$ of sample per min under the condition indicated. The enzyme protein concentration was determined by the Lowry method with BSA as the standard (Plummer, 1978).

\section{Statistical Analysis}

The data in the main study were analyzed as a $4 \times 3$ factorial arrangement. The differences of mean value were analyzed by Duncan's new multiple range test (Steel and Torrie, 1980).

\section{RESULTS AND DISCUSSION}

\section{Results}

Addition of saponin significantly $(\mathrm{P}<0.01)$ inhibited the protozoa growth in vitro fermentation fluid and decreased ammonia concentration, but other parameters ( $\mathrm{pH}$, microbial protein, and cellullase activity) were unaffected. The protozoa numbers were reduced by $17.22,42.73$, and $49.57 \%$ for $0.1,0.2$, and 0.3 $\mathrm{mg} / \mathrm{ml}$ saponin, respectively from $8.19 \times 10^{3} / \mathrm{ml}$ in the control. The addition of 0.2 and $0.3 \mathrm{mg} / \mathrm{ml}$ saponin decreased ammonia concentrations by 1.69 and $16.50 \%$, respectively compared to the control, with the lowest concentration in $0.3 \mathrm{mg} /$ $\mathrm{ml}$ saponin $(27.59 \mathrm{mg} / 100 \mathrm{ml})$. The addition of $0.1 \mathrm{mg} / \mathrm{ml}$ saponin increased ammonia concentration compared to control. Cellullase activity was $30.13 \%$ lower in addition of $0.3 \mathrm{mg} /$ $\mathrm{ml}$ saponin than in the controls, but this difference was not statistically significant $(\mathrm{P}>0.05)$.

Kind of feed also influenced significantly $(\mathrm{P}<0.01)$ on protozoal numbers and ammonia concentration, but it didn't affect on $\mathrm{pH}$, microbial protein, as well as cellullase activity. Protozoa numbers in fermentation with king grass and king grass-rice bran as substrate were lower than that of rice bran, which were 21.34 and $24.83 \%$ lower than the control $\left(7.45 \times 10^{3} / \mathrm{ml}\right)$. The ammonia concentration with rice bran and king grass-rice bran were higher than that with king grass, and the highest concentration was in rice bran $(37.65$ $\mathrm{mg} / 100 \mathrm{ml})$.

In general, no interactions between saponin and kind of feed were observed. Except for ammonia concentration, which were reached the lowest concentration $(23.53 \mathrm{mg} / 100 \mathrm{ml})$ by the addition of $0.3 \mathrm{mg} / \mathrm{ml}$ saponin and king grass as a substrat.

Table 1. In vitro Fermentation Parameters at Different Level of Saponin and Kind of Feeds

\begin{tabular}{|c|c|c|c|c|c|c|c|c|c|c|c|c|c|c|c|}
\hline \multirow{2}{*}{ Parameters } & \multicolumn{4}{|c|}{ King grass } & \multicolumn{4}{|c|}{ Rice bran } & \multicolumn{4}{|c|}{ King grass-rice bran } & \multicolumn{3}{|c|}{ Significance } \\
\hline & 0 & 0.1 & 0.2 & 0.3 & 0 & 0.1 & 0.2 & 0.3 & 0 & 0.1 & 0.2 & 0.3 & $\mathrm{KF}$ & SPN & INT \\
\hline Protozoal numbers & & & & & & & & & & & & & & & \\
\hline$\left(\mathrm{x} 10^{3} / \mathrm{ml}\right)$ & 8.62 & 6.00 & 4.87 & 3.94 & 7.69 & 6.00 & 4.69 & 4.03 & 8.25 & 8.34 & 6.75 & 6.47 & $* *$ & $* *$ & $\mathrm{~ns}$ \\
\hline $\mathrm{pH}$ & 7.02 & 6.97 & 6.99 & 7.00 & 7.06 & 6.99 & 7.05 & 7.03 & 7.06 & 7.05 & 7.05 & 7.03 & $\mathrm{~ns}$ & $\mathrm{~ns}$ & $\mathrm{~ns}$ \\
\hline $\begin{array}{l}\text { Ammonia } \\
\text { concentration } \\
(\mathrm{mg} / 100 \mathrm{ml})\end{array}$ & 24.12 & 28.03 & 26.53 & 23.53 & 37 & 34.89 & 35.9 & 30.07 & 37.99 & 48.44 & 34.99 & 29.19 & $* *$ & $* *$ & $* *$ \\
\hline $\begin{array}{l}\text { Cellullase activity } \\
(\mathrm{U} / \mathrm{g})\end{array}$ & 1.53 & 1.37 & 1.04 & 0.73 & 0.84 & 1.17 & 1.07 & 2.52 & 0.92 & 0.69 & 0.61 & 1.41 & $\mathrm{~ns}$ & $\mathrm{~ns}$ & $\mathrm{~ns}$ \\
\hline $\begin{array}{l}\text { Microbial protein } \\
(\mathrm{mg} / \mathrm{ml})\end{array}$ & 0.25 & 0.31 & 0.32 & 0.29 & 0.27 & 0.23 & 0.32 & 0.25 & 0.25 & 0.29 & 0.21 & 0.26 & $\mathrm{~ns}$ & $\mathrm{~ns}$ & $\mathrm{~ns}$ \\
\hline
\end{tabular}

$$
\text { ** } \mathrm{P}<0.01
$$

KF kind of feeds

SPN level of saponin (\%)

INT interaction 


\section{Discussion}

Microbial proteins were apparently unaltered by saponin, but protozoal numbers have shown that saponin affects the protozoa growth, and tended to increase cellullase activity. Included at $1 \%$, Yucca schidigera extract stimulated Prevotella ruminicola, suppressed Streptococcus bovis and Butyrivibrio fibrisolvens and did not affect growth of Selenomonas ruminantium (Wallace et al., 1994). Decreasing protozoal counts with supplementation of saponins rich extract (Hristov et al., 1999) or pod and seed (Patra et al., 2006) or fruits (saponin-rich fruits including S. saponaria (Diaz et al., 1993; Hess et al., 2003) have been reported. Saponins possibly bind with sterol of cell membrane of protozoa and change the permeability of cell membrane (Patra et al., 2006). The most widely recognized biological effect of saponins is the haemolysis of red blood cells in vitro. It is generally accepted that saponins cause haemolysis by increasing the permeability of the plasma membrane (Price et al., 1987). Saponins from various sources have also been found to permeabilize the small intestinal mucosal cells of mammals (Johnson et al., 1986), but the effect of saponins on the permeability of microbial cell walls has not been assessed. Klita et al. (1996) explained the susceptibility of rumen protozoa and lack of susceptibility of rumen bacteria to saponins by the presence of cholesterol in eukaryotic membrane (including protozoa), but not in prokaryotic bacteria cells.

The cellullase activities were not affected by saponin. Patra et al. (2006) demonstrated the specific activities of CMCase were not affected by any of the extracts tested, whereas specific activity of acetylesterase reduced significantly $(\mathrm{P}<0.05)$ by all the extracts. The numerically lower activities in the presence of different extracts on CMCase and xylanase might be due to its antiprotozoal activity, as it has been reported that about $38 \%$ of cellulase activity is associated with protozoa fraction of rumen liquor (Agarwal et al., 1991 cit. Patra et al., 2006). A decrease in CMCase and xylanase activity by addition of yucca and quillaja saponins have been observed by Hristov et al. (2003).

The addition of $0.3 \mathrm{mg} / \mathrm{ml}$ saponin resulted in the lowest ammonia-N concentration. Hussain and Cheeke (1995) considered that the reduction in ammonia-N by saponins was due to the reduced urease activity, but Headon et al. (1991) cit. Hu (2005) explained it by ammonia binding properties of saponins. In the result study, Pen et al. (2006) demonstrated that NH3-N concentrations were reduced $(\mathrm{P}<0.001)$ by up to $48 \%$ with Yucca schidigera extract and tended to decrease by up to $21 \%$ by Quillaja saponaria extract. Yucca extract has two fractions, the glycofractions and saponins, and reduced $\mathrm{NH} 3-\mathrm{N}$ concentrations may be due to the ammonia binding ability of the glycofractions, while the saponin fraction may affect ammonia concentrations indirectly via toxicity to rumen ciliate protozoa (Wallace et al., 1994). Reduced ammonia concentrations in the rumen are typical when protozoal growth is inhibited, presumably as a result of depressed bacterial lysis (Pen et al., 2006).

\section{CONCLUSION}

In conclusion, supplying at $0.2 \mathrm{mg} / \mathrm{ml}$ saponin in vitro gas production buffer has antimicrobial properties, particularly in suppressing protozoa and reduce ammonia concentration, which may prove beneficial to ruminal fermentation and may lead to lower ruminal ammonia concentration, but it did not have negative effect on $\mathrm{pH}$, microbial protein and cellullase activity. Using king grass as a substrat decreases protozoal numbers and ammonia concentration..

\section{REFERENCES}

Abreu, A., J.E. Carulla, C.E. Lascano, T.E. Diaz, M. Kreuzer and H.D. Hess. 2004. Effects of Sapindus saponaria fruits on ruminal fermentation and duodenal nitrogen flow of sheep fed a tropical grass diet with and without legume. J. Anim. Sci. 82:13921400.

Diaz, A., M. Avendano and A. Escobar. 1993. Evaluation of Sapindus saponaria as a defaunating agent and its effects on different ruminal digestion parameters. Livest. Res. Rural Dev. 5:1-6.

Halliwell, G., M.N.B.A. Wahab and A.H. Patel. 1985. Chemical composition of endo-1,4- $\beta$ D-Cellulotic in Trichoderma koningi. J. App. Biochem. 7:43-45.

Hess, H.D., M. Kreuzer, T.E. Diaz, C.E. Lascano, J.E. Carulla, C.R. Soliva and A. Machmuller. 2003. Saponin rich tropical fruits affect fermentation and methanogenesis in faunted and defaunated 
rumen fluid. Anim. Feed Sci. Technol. 109:79-94.

Hristov, A.N., T.A. McAllister, F.H. Van Herk, K.J.Cheng, C.J. Newbold and P.R. Cheeke. 1999. Effect of Yucca schidigera on ruminal fermentation and nutrient digestion in heifers. J. Anim. Sci. 77:2554-2563.

Hristov, A.N., M. Ivan, L. Neill and T.A. McAllister. 2003. Evaluation of several potential bioactive agents for reducing protozoal activity in vitro. Anim. Feed Sci. Technol. 105:163-184.

Hu, W.L., J-X. Liu, J.-A. Ye, Y.M. Wu and Y.Q. Guo. 2005. Effect of tea saponin on rumen fermentation in vitro. Anim. Feed Sci. Technol. 120:333-339

Hussain, I. and P.R. Cheeke. 1995. Effect of Yucca Schidigera extract on rumen and blood profiles of steers fed concentrate- or roughage-based diets. Anim. Feed Sci. Technol. 51:231-242.

Johnson, I.T., J.M. Gee, K.R. Price, C.L. Curl and G.R. Fenwick. 1986. Influence of saponins on gut permeability and active nutrient transport in vitro. J. Nutr. 116:2270-2277.

Klita, P.T., G.W. Mathison, T.W. Fenton and T.R. Hardin. 1996. Effects alfalfa root saponins on digestive function in sheep. J. Anim. Sci. 74:1144-1156.

Menke, K.H., and H. Steingass. 1988. Estimation of the energetic feed value obtained by chemical analysis and in vitro gas production using rumen fluid. Anim. Res. Dev. 28:7-55.

Orskov, E.R., W.P. Flatt and P.W. Moe. 1968. Fermentation Balance Approach to Estimate Extent of Fermentation and Efficiency of Volatile Fatty Acid Formation in Ruminants. Animal Husbandry Research Division, USDA, Beltsvilie, Maryland.
Patra, A.K., D.N. Kamra and N. Agarwal. 2006. Effect of plant extracts on in vitro methanogenesis, enzyme activities and fermentation of feed in rumen liquor of buffalo. Anim. Feed Sci. Technol. 128:276291.

Pen, B., C. Sar, B. Mwenya, K. Kuwaki, R. Morikawa and J. Takahashi. 2006. Effects of Yucca schidigera and Quillaja saponaria extracts on in vitro ruminal fermentation and methane emission. Anim. Feed Sci. Technol. 129:175-186

Plummer, D. T. 1978. An Introduction to Practical Biochemistry. Tata Mc Graw Hill Publ. Co. Ltd. Bombay New Delhi.

Price, K.R., I.T. Johnson and G.R. Fenwick. 1987. The chemistry and biological significance of saponins in foods and feedstuffs. CRC Crit. Rev. Food Sci. Nutr. 26:27-135.

Segal, R., M. Mansour and D.V. Zaitschek. 1966. Effect of ester groups on the haemolytic action of some saponins and sapogenins. Biochem. Pharmacol. 15:1411-1416.

Steel, R.D.G. and Torrie, J.H., 1980. Principles and Procedures of Statistics. $2^{\text {ed }}$. McGrawHill Book Co.Inc. New York.

Wallace, R.J., L. Arthaud and C.J. Newbold. 1994. Influence of Yucca shcidigera extract on ruminal ammonia concentrations and ruminal microorganisms. Appl. Environ. Microbiol. 60:1762-1767.

Wang, Y., T.A. McAllister, L.J. Yanke and P.R. Cheeke. 2000. Effect of steroidal saponins from Yucca schidigera extract on ruminal microbes. J. Appl. Microbiol. 88:887-896.

Weatherburn, M.W. 1967. Phenol-hypochlorite reaction for the determination of ammonia. Anal. Chem. 39:971-974. 